\title{
ОПРІСНЕННЯ МОРСЬКОЇ ВОДИ ДЛЯ ОТРИМАННЯ ЗЕЛЕНОГО ВОДНЮ
}

\author{
С.О. Кудря, д-р техн. наук, Л.В. Яценко, Л.Я. Шинкаренко, М.А. Ткаленко, канд. техн. наук
}

Інститут відновлюваної енергетики НАН України,

02094, вул. Гната Хоткевича, 20А, м. Київ, Україна

Проблематика розвитку вітроводневої офшорної енергетики Украӥни полягає у необхідності створення ефективної системи постачання прісної води для виробництва зеленого водню електролітичним методом. Використання водневих технологій дозволяє оптимізувати роботу вітроенергетичної системи й досягти більшої економічної ефективності вітроелектричного обладнання, оскільки забезпечується безперервність роботи генерувальної вітроелектричної станції.

Участь Украӥни в європейській програмі «2x40 GW Green Hydrogen Initiative», відповідно до якої в Україні передбачається встановлення 10 ГВт нових потужностей електролізерів для виробництва зеленого водню, потребує детальної розробки відповідної інфраструктури морських ВЕС, насамперед систем опріснення морської води для зменшення логістичних витрат на ї̈ доставку.

У роботі проведено аналіз сучасних методів опріснення і визначено, що найбільш прийнятним на сьогодні є метод зворотного осмосу, який має істотні переваги: відносно невисокі експлуатаційні витрати, проста та компактна конструкиія. Робота такої системи може бути легко автоматизована, тому управління нею здійснюється в напівавтоматичному $i$ автоматичному режимі.

Встановлено, що роботу електролізера потужністю 1 МВт разом із системою опріснення забезпечує офшорна ВЕС потужністю 2 МВт. Розрахункові показники, представлені в роботі, мають орієнтовний характер і рекомендуються до використання як попередні вихідні дані при розробиі конкретних проєктів різної потужності, де вони будуть уточнюватися з урахуванням всіх факторів - характеристик морської води, вітроенергетичного, електролітичного та опріснювального обладнання, щзо входитиме до складу морського комплексу з отримання зеленого водню, тощо.

Масштабне виробництво електролітичного водню за допомогою офиорної вітрової енергї забезпечить зміну структури паливно-енергетичного комплексу України за рахунок збільшення в ньому вітрової енергії, підвищення стабільності роботи вітроелектричного обладнання, ефективності та надійності електропостачання, а також матиме позитивний вплив на навколишнє середовище. Бібл. 20, рис.1. табл. 1.

Ключові слова: офиорна вітроенергетика, воднева енергетика, електроліз води, опріснення морської води.

\section{DESALINATION OF SEA WATER FOR PRODUCTION OF GREEN HYDROGEN}

\author{
S. Kudrya, doctor of technical science, L.Yatsenko, L. Shynkarenko, M. Tkalenko, candidate of technical science \\ Institute of Renewable Energy of the National Academy of Sciences of Ukraine, \\ 02094, 20A Hnata Khotkevycha St., Kyiv, Ukraine
}

The problem of development of offshore wind energy in Ukraine is the need to create an efficient system of fresh water supply for the production of green hydrogen by electrolytic method. The use of hydrogen technologies allows to optimize the operation of the wind power system and achieve greater economic efficiency of wind power equipment, as it ensures the continuity of the generating wind power plant.

Ukraine's participation in the European program "2x40 GW Green Hydrogen Initiative", according to which Ukraine envisages the installation of $10 \mathrm{GW}$ of new capacities for the electrolytic production of green hydrogen, requires detailed development of appropriate marine wind farm infrastructure, especially seawater desalination systems to reduce logistics costs on its delivery.

The analysis of modern desalination methods is carried out and it is determined that the most acceptable method today is reverse osmosis, which has significant advantages: relatively low operating costs, simple and compact design. The operation of such a system can be easily automated, so they are controlled in a semi-automatic and automatic mode.

It is established that the operation of a 1 MW electrolytic cell together with a desalination system is provided by an offshore wind farm with a capacity of $2 \mathrm{MW}$. The calculated indicators presented in the paper are indicative and are recommended for use as preliminary

(С С.О. Кудря, Л.В. Яценко, Л.Я. Шинкаренко, М.А. Ткаленко, 2021

Відновлювана енергетика. 2021. № 4 
initial data in the development of specific projects of different capacity, which will be specified taking into account all factors characteristics of sea water, wind, electrolytic and desalination equipment to obtain green hydrogen, etc.

Large-scale production of electrolytic hydrogen using offshore wind energy will change the structure of Ukraine's fuel and energy complex by increasing wind energy, increasing the stability of wind power equipment, efficiency and reliability of electricity supply, and will have a positive impact on the environment. Bibl. 20, fig.1, table 1.

Keywords: offshore wind power, hydrogen energy, electrolysis of water, desalination of sea water.

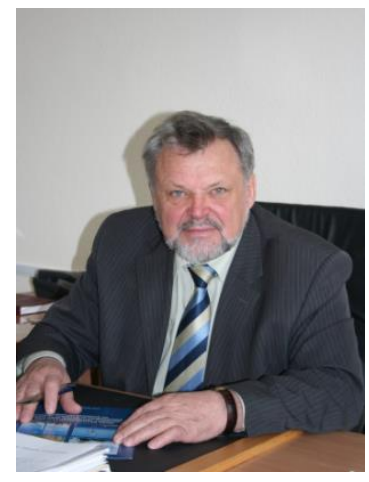

\section{C.O. Кудря S. Kudrya}

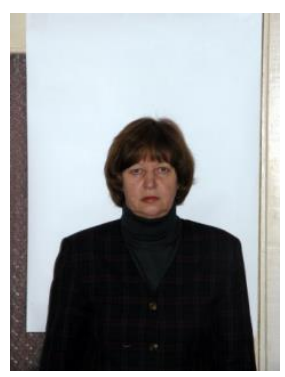

Л.В. Яиенко L. Yatsenko

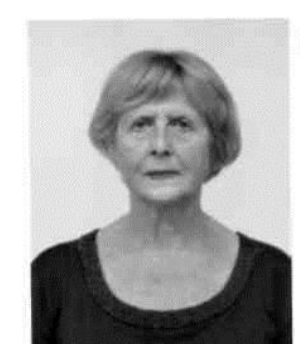

Л.Я. Шинкаренко L. Shynkarenko

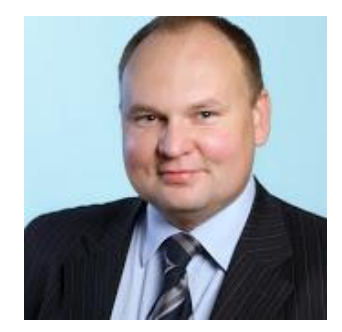

М.Д. Ткаленко M. Tkalenko
Відомості про автора: член-кореспондент НАН України, доктор технічних наук, професор, директор Інституту відновлюваної енергетики НАН України

Освіта: закінчив у 1971 р. Київський політехнічний інститут за спеціальністю «Технологія електрохімічних виробництв» Наукова сфера: відновлювані джерела енергії, акумулювання енергії, воднева енергетика

Публікації: 378

ORCID: 0000-0002-4798-6853

Контакти: +38(044) 206-28-09

e-mail: renewable@ukr.net

sa.kudria@gmail.com

Відомості про автора: науковий співробітник Інституту відновлюваної енергетики НАН України

Освіта: закінчила в 1976 р. Київський політехнічний інститут за спеціальністю «Технологія електрохімічних виробництв» Наукова сфера: відновлювані джерела енергії, акумулювання енергії, воднева енергетика

Публлікації: 89

ORCID: 0000-0001-7022-1579

Контакти: +38(044) 206-28-09

e-mail: renewable@ukr.net

Відомості про автора: молодший науковий співробітник Інституту відновлюваної енергетики НАН України

Освіта: закінчила в 1978 р. Київський політехнічний інститут за спеціальністю «Технологія електрохімічних виробництв» Наукова сфера: відновлювані джерела енергії, акумулювання енергії, воднева енергетика

Публікації: 19

ORCID: 0000-0003-2018-3329

Контакти: +38(044) 206-28-09

e-mail: renewable@ukr.net

Відомості про автора: старший науковий співробітник Інституту відновлюваної енергетики НАН України

Освіта: закінчив у 1996 р. Київський політехнічний інститут за спеціальністю «Технічна електрохімія»

Наукова сфера: відновлювані джерела енергії, акумулювання енергії, воднева енергетика

Публікації: 79

ORCID: 0000-0003-0698-5739

Контакти: +38(044)206-28-09

e-mail: renewable@ukr.net
Author information: corresponding member of NAS of Ukraine, Doctor of Technical Sciences, Professor, Director of the Institute of Renewable Energy NAS of Ukraine Education: granduated from the Kyiv Polytechnic Institute in 1971 with a degree «Electrochemical Productions Technology» Research area: renewable energy sources, energy storage, hydrogen energy

Publications: 378

ORCID: 0000-0002-4798-6853

Contacts: $+38(044) 206-28-09$

e-mail: renewable@ukr.net

sa.kudria@gmail.com

Author information: researcher at Institute of Renewable Energy, National Academy of Sciences of Ukraine.

Education: granduated from the Kyiv

Polytechnic Institute in 1976 with a degree «Electrochemical Productions Technology». Research area: renewable energy sources, energy storage, hydrogen energy.

Publications: 89

ORCID: 0000-0001-7022-1579

Contacts: +38(044)206-28-09

e-mail: renewable@ukr.net

Author information: junior researcher at Institute of Renewable Energy, National Academy of Sciences of Ukraine.

Education: granduated from the Kyiv

Polytechnic Institute in 1978 with a degree «Electrochemical Productions Technology» Research area: renewable energy sources, energy storage, hydrogen energy.

Publications: 19

ORCID: 0000-0003-2018-3329

Contacts: +38(044)206-28-09

e-mail: renewable@ukr.net

Author information: researcher fellow at Institute of Renewable Energy, National Academy of Sciences of Ukraine

Education: granduated from the Kyiv Polytechnic Institute in 1996 with a degree «Technical electrochemistry»

Research area: renewable energy sources, energy storage, hydrogen energy

Publications: 79

ORCID: 0000-0003-0698-5739

Contacts: +38(044)206-28-09

e-mail: renewable@ukr.net 


\section{Перелік використаних позначень та скорочень:}

GWEC - Глобальна рада з вітроенергетики;

ВЕС - вітроелектростанція;

ГЕС - гідроелектростанція;

Wind Europe - Свропейська вітроенергетична асоціація;

NREL - Національна лабораторія відновлюваної енергетики США;

ККД - коефіцієнт корисної дії;

$$
\begin{aligned}
& \text { НДР - науково-дослідні роботи; } \\
& \text { РЕМ - протонообмінні мембрани; } \\
& \text { нм³ - нормальний метр кубічний; } \\
& \mathrm{H}_{2} \text { - водень; }
\end{aligned}
$$

SOEC - твердооксидний електролізер.
Вступ. Поряд зі стрімким розвитком безвуглецевої енергетики у провідних енергетичних компаніях світу i масштабним переходом країн на відновлювані джерела енергії почалось значне збільшення ринку офшорної вітроенергетики. Згідно з даними Глобальної ради 3 вітроенергетики (Global Wind Energy Council, GWEC) починаючи 32013 року офшорний вітроенергетичний ринок збільшувався щороку в середньому на $24 \%$, у результаті чого на кінець 2019 року загальна потужність офшорних вітроенергетичних проєктів досягла 29100 МВт, або 5 \% загальної вітроенергетичної потужності світу [1].

Усі перші офшорні ВЕС були побудовані здебільшого європейськими країнами $\mathrm{i}$ не перевищували 100 МВт встановленої потужності, що було обумовлено насамперед дорожнечею офшорного вітроенергетичного обладнання та відсутністю відповідної державної політики. Основна частина витрат при встановлені та експлуатації офшорної ВЕС спрямовується на електричне з'єднання як між турбінами в межах електростанції, так і між електростанцією i електричною мережею на суші. Оскільки виробіток офшорної ВЕС завжди на порядок вищий від наземної $\mathrm{BEC}$ через потужніший вітровий ресурс (10\% збільшення середньої швидкості вітру потенційно означає $30 \%$ збільшення вироблення електроенергії), то при виробленні надлишку електроенергії виникає проблема, для вирішення якої необхідно обмежувати генерацію, включно до примусового відключення електростанції [1].

Широкий розвиток отримало будівництво BEC на шельфі у прибережних, в основному мілководних, акваторіях Данії, Нідерландів, Швеції, Великої Британії та інших країн. Нідерландами у Північному морі було запущено один із найбільших у світі офшорних вітропарків «Gemini», що складається зі 150 турбін загальною потужністю 600 МВт. Також Нідерланди, Данія і Німеччина підписали спільну угоду в Брюсселі про будівництво штучного острова, який розташовуватиметься на найбільшій піщаній мілині у Північному морі й обслуговуватиме потужну вітрову електростанцію (за планами енергію вироблятимуть понад 10 тис. вітрових турбін) [2].

Консорціум корейських дослідних інститутів i суднобудівна компанія Daewoo Shipbuilding \& Marine Engineering (DSME) розробили проєкт плавучої морської установки Hydrogen FPSO 3 виробництва водню, його зберігання і поставок. Конструкція працюватиме від енергії вітру. Планується запуск пілотної установки до 2022 року, а повномасштабні комерційні операції на ній - до 2030 року [3].

Україна має значний технічно-досяжний потенціал розвитку офшорної вітроенергетики на мілководних територіях великих акваторій: Азовського та Чорного морів, затоки Сиваш, 
водосховищ Дніпровського каскаду ГЕС, лиманів. За даними дослідження Національної лабораторії відновлюваної енергетики NREL (США) площа мілководдя дозволяє побудувати в Україні офшорні ВЕС потужністю 146 ГВт. Потенціал офшорних ВЕС в Україні, уточнені значення якого розраховані у відділі вітроенергетики Інституту відновлюваної енергетики НАН України, становить майже 250 ГВт. 3 урахуванням реального середнього коефіцієнта встановленої потужності для офшорних ВЕС України, який складає 0,45 , відповідний річний виробіток електроенергії становитиме близько 1000 млрд кВт·год, що більш ніж ушестеро перевищує поточне річне споживання електроенергії в Україні [4].

За даними Wind Europe (Свропейська вітроенергетична асоціація), коефіцієнт встановленої потужності нових офшорних ВЕУ одиничною потужністю 10 МВт може становити до 0,6. У такому разі обсяг виробництва електроенергії на офшорних ВЕС України може перевищувати прогнози IBE НАН України.

Зважаючи на бурхливий розвиток світової водневої енергетики, ефективним шляхом вирішення проблеми надлишку виробництва електроенергії офшорними ВЕС $є$ створення акумулювальних потужностей за рахунок виробництва водню.

У проєкті BEHYOND, який був відібраний для підтримки Програмою блакитного зростання Фінансового механізму Європейського економічного простору (the Blue Growth Programme of the European Economic Area Financial Mechanism(EEA Grants), буде розроблено концептуальне інженерно-економічне обгрунтування для нової офшорної системи виробництва зеленого водню 3 морського вітру. Дослідження включає інноваційну інтеграцію обладнання для виробництва і кондиціонування зеленого водню та інфраструктури, що дозволяє транспортувати його до узбережжя. Основною метою є створення унікальної концепції, яка може бути стандартизована та впроваджена в усьому світі, забезпечуючи широкомасштабне виробництво водню [5].

Польща позиціонує плани зі створення водневої магістралі для транспортування на південь зеленої електроенергії та водню 3 офшорних ВЕС Балтійського моря, Бельгія та Сполучене Королівство працюють над об'єднанням ї офшорних ВЕС в єдину енергетичну систему Північного моря, а Данія планує створення енергетичних хабів офшорних BEC із виробництва зеленого водню потужністю $12000 \mathrm{MBт,} \mathrm{які} \mathrm{можуть} \mathrm{бути} \mathrm{приєднані} \mathrm{до}$ енергомереж інших країн Європи [1].

За результатами досліджень, проведених IBE НАН України, потенціал потужностей офшорних ВEC України може забезпечити середньорічне виробництво 219 млрд нм ${ }^{3}$ (19,5 млн т) зеленого водню методом електролізу. В результаті проведених досліджень встановлено, що Україна має високий середньорічний технічний потенціал виробництва зеленого водню $\approx 500$ млрд нм ${ }^{3} /$ рік, що забезпечило іï участь в європейській програмі «2х40 GW Green Hydrogen Initiative», відповідно до якої в Україні буде встановлено 10 ГВт нових потужностей електролізерів для виробництва «зеленого» водню. Вказана ініціатива передбачає встановлення 2 ГВт нових потужностей електролізерів для внутрішнього ринку і 8 ГВт для експорту водню трубопроводами до ЄС [4]. 
Основною ресурсною базою сучасної морської зеленої водневої енергетики, що виробляє водень шляхом електролітичного розкладу води, $€$ використання енергії відновлюваних джерел та водних ресурсів.

Постановка задачі. Виробництво водню безпосередньо від офшорних ВЕС сприятиме підвищенню ринкового потенціалу офшорних вітроенергетичних проєктів та рівня декарбонізації економіки в Україні. Визначення перспективних напрямів опріснення морської води та створення на їх основі відповідної інфраструктури офшорних ВЕС для виробництва водню методом електролітичного розкладу води сприятиме зменшенню логістичних витрат на забезпечення технологічних потреб у прісній воді.

На енергетичну та економічну ефективність системи опріснення основний вплив має вибір методу опріснення. На даний час промислове застосування мають дві основні технології опріснення морської води - дистиляція, або термальна технологія, та мембранна технологія, найбільш вживаним методом якої $є$ зворотний осмос.
До 1980-х років 84 \% всієї знесоленої води отримували із застосуванням термічних методів. У 2000-му термічні методи та зворотний осмос практично зрівнялися в обсягах виробництва відповідно 11,6 і 11,4 млн м³/добу, що загалом становило 93 \% всієї знесоленої води. Сьогодні зворотним осмосом отримують 65,5 млн м³/добу знесоленої води, тобто 69 \% всієї знесоленої води, а частка виробництва води заводами на основі мембран становить $84 \%$ [6].

Суть методу зворотного осмосу полягає у продавлюванні води під високим тиском через напівпроникну мембрану 3 метою усунення розчинених речовин, органіки, колоїдних часток та бактерій. Невеликі молекули води можуть вільно проникати крізь мікропори мембран, тоді як більш великі іони солей та інші домішки затримуються мембраною. Важливо відзначити, що для солонуватої та солоної води застосовуються спеціальні мембранні елементи, які мають високу селективність по іонах натрію $\mathrm{i}$ хлору [7].

Схема опріснення морської води методом зворотного осмосу показана на рис. 1 [6].

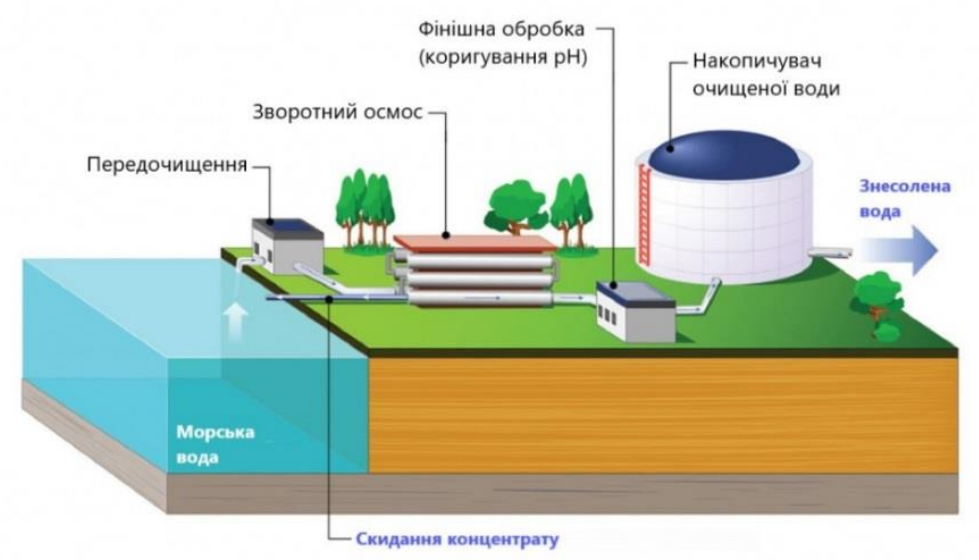

Рис. 1. Схема опріснення морської води методом зворотного осмосу

Fig. 1. Scheme of seawater desalination by reverse osmosis 
Порівняно $з$ іншими методами опріснення води зворотний осмос має істотні переваги: відносно невисокі експлуатаційні витрати, проста й компактна конструкція. Робота систем зворотного осмосу може бути легко автоматизована, тому управління ними здійснюеться в напівавтоматичному i автоматичному режимах. При застосуванні методу зворотного осмосу за відсутності агресивних реагентів і необхідності їх обробки отримують прісну воду високої якості щодо біологічних та органічних забруднень. Крім того, перевагою системи зворотного осмосу $\epsilon$ можливість створювати установки змішаного типу, що дозволяє оптимізувати продуктивність у разі значних коливань добового або сезонного співвідношення між виробництвом води та електроенергії.

Джерелом енергії для систем зворотного осмосу є електроенергія, що використовується для роботи багатоступеневих насосів високого тиску, ККД яких зазвичай варіюється від 65 до 85 \%. Для рекуперації частини витраченої насосами енергії іноді застосовуються регенераційні насоси, призначенням яких є використання залишкового високого тиску, що утворюється на виході 3 установки. Регенерація тиску дозволяє скоротити енерговитрати опріснювальної установки на 25-28 \%. Кількість електроенергії, необхідної для системи зворотного осмосу, оснащеної регенераційним модулем, становить зазвичай від 4 до 8,5 кВт·год $/ \mathrm{M}^{3}$ опрісненої води. Електроспоживання визначається переважно робочим тиском, який в свою чергу залежить від якості води, що надходить для опріснення. Капіталовкладення для обладнання на основі зворотного осмосу варіюються в межах 600-1200 доларів США на м³/день залежно від якості вихідної солоної води і загальної схеми опріснювальної установки. Одномодульна система може щоденно виробляти близько 4000-7000 м³ і більше прісної води [8].

У світі тривають дослідження щодо удосконалення існуючих технологій опріснення та пошук альтернативних можливостей. Над удосконаленням методу зворотного осмосу активно працюють протягом останніх 40 років. Головною проблемою $є$ удосконалення напівпроникних мембран, крізь які проходить мінералізована вода, для зменшення витрат електроенергії на продавлювання через них води. Група дослідників із Техаського університету в Остіні та Державного університету Айови заявила про покращення дієвості технології зворотного осмосу для опріснення морської води на $30-40 \%$ [9].

Компанія Thames Water запустила перший у Великобританії завод 3 опріснення води зворотним осмосом, який використовує 4ступеневий метод опріснення води. У Лондоні розробляються ще ефективніші технології британська компанія Modern Water проводить комерційне випробування системи опріснення, перший етап якого називають прямим осмосом. У компаніï Modern Water стверджують, що метод прямого осмосу може знизити витрати на енергію до $30 \%$ [10].

Французька компанія Lhyfe в промислових масштабах виробляє відновлюваний «зелений» водень з електролізера, що працює безпосередньо від вітрових турбін, обсягом 300 кг на день і незабаром планує наростити обсяги виробництва до однієї тонни на день. Виробництво водню проводиться на ділянці, розташованій біля океану в Порт-дю-Бек (Франція); водень постачатиметься 
на чотири заправні станції, які мають запрацювати найближчими днями. Зібраний капітал дозволить Lhyfe інвестувати 30 млн євро у зміцнення своїх груп розгортання досліджень і розробок у Франції та інших країнах. У напрямку проведення НДР планується прискорення виробництва водню від вітрових турбін на морі з впровадженням першого демонстратора видобутку водню на пілотному майданчику біля узбережжя Ле-Круазік з 2022 року та розробка нових проєктів [11].

Компанія Nel ASA заявила про поставку електролізера РЕМ мегаватного масштабу для проєкту PosHYdon, метою якого $є$ перевірка інтеграції морського водню, вітру та природного газу на Nepture Energy-operated Q13a-A platform в офшорних Нідерландах. Q13a-A - перша повністю електрифікована платформа в Північному морі Нідерландів, яка перетворює морську воду в демінералізовану воду, а потім - у зелений водень шляхом електролізу. Передбачається, що електролізер потужністю $1,25 \mathrm{MB}$ в вироблятиме максимум 500 кг $\left(5500 \mathrm{м}^{3}\right)$ «зеленого» водню на день. Через пілотну програму консорціум хоче отримати досвід інтеграції робочих енергетичних систем на морі та виробництва водню в морському середовищі. Зелений водень буде змішаний 3 газом i транспортуватиметься існуючим газопроводом до узбережжя [12].
Процес виробництва водню електролізом води вигідно відрізняється від інших методів відносно простим апаратурним та технологічним оформленням. Теоретично для виробництва 1 нм$^{3}$ водню потрібно 0,81 л води та 3,5 кВт.год електроенергії при температурі $25^{\circ} \mathrm{C}$ та атмосферному тиску. На практиці для виробництва 1 нм $^{3} \mathrm{H}_{2}$ використовується 1,5-2,0 л води та 4,5 кВт.год електроенергії. Через деяку неефективність у процесі, враховуючи процес демінералізації води, при типовому споживанні витрати води складають від 18-24 кг на 1 кг водню. При роботі дуже великого електролізера потужністю 1 ГВт, що працює 8000 годин на рік 3 ефективністю $75 \%$, річне виробництво водню складе 0,15 млн т, а витрати - 3 млн т води (iз розрахунку 20 кг води на кілограм водню) $[4,13,14]$.

Наведені в табл. 1 розрахункові дані орієнтовані на використання 4,5 кВТ·год електроенергії та $0,002 \mathrm{~m}^{3}$ прісної води для отримання $1 \mathrm{Hм}^{3}$ водню електролітичним розкладом води при ККД електролізера 0,8 та роботі протягом максимальної кількості робочих годин за рік. Потребу в електроенергії для опріснення методом зворотного осмосу прийнято 4 кВт·год/м ${ }^{3}$ опрісненої води.

Таблиця 1. Енергетичні витрати на отримання «зеленого» водню

Table 1. Energy costs for obtaining green hydrogen

\begin{tabular}{|c|c|c|c|c|c|c|}
\hline $\begin{array}{c}\text { Потужність } \\
\text { електролізера }\end{array}$ & $\begin{array}{c}\text { Потреба в } \\
\text { електроенергії, } \\
\text { млн кВт·год }\end{array}$ & $\begin{array}{c}\text { Виробництво } \\
\text { водню, } \\
\text { млн нм }\end{array}$ & $\begin{array}{c}\text { Потреба в } \\
\text { прісній } \\
\text { воді, } \\
\text { млн м }\end{array}$ & $\begin{array}{c}\text { Кількість } \\
\text { електро- } \\
\text { енергії на } \\
\text { опріснення, } \\
\text { млн кВт·год }\end{array}$ & $\begin{array}{c}\text { Загальна } \\
\text { кількість } \\
\text { електроенергії на } \\
\text { виробництво } \\
\text { водню, } \\
\text { млн кВт·год }\end{array}$ & $\begin{array}{r}\text { Необхідна } \\
\text { потужність } \\
\text { ВЕС, МВТ }\end{array}$ \\
\hline $1 \mathrm{MBT}$ & 7,01 & 1,56 & 0,003 & 0,012 & 7,02 & $2 \mathrm{MBT}$ \\
\hline $1 \Gamma \mathrm{BT}$ & 7010 & 1560 & 3,12 & 12,5 & 7022 & $2 \Gamma \mathrm{BT}_{\mathrm{T}}$ \\
\hline 10 ГВТ & 70100 & 15600 & 31,2 & 125 & 70225 & $20 \Gamma \mathrm{B}_{\mathrm{T}}$ \\
\hline
\end{tabular}


Як видно, енергетичні витрати на опріснення морської води методом зворотного осмосу становлять незначну частку загальних витрат на виробництво водню. Офшорна ВЕС потужністю $1 \mathrm{MB}$ із коефіцієнтом корисного використання 0,45 при постійній роботі протягом року може виробляти близько 4 млн кВт•год електроенергії. Отже, загальні енергетичні витрати $1 \mathrm{MB}$ електролізних потужностей забезпечуються роботою офшорних ВЕС потужністю 2 МВт.

Оскільки солоність води в різній місцевості має різні показники, а обладнання для отримання електроенергії, електролізу та опріснення морської води також має різні параметри роботи, при подальших розрахунках показники, представлені в таблиці, мають орієнтовний характер. Як кількість електроенергії, виробленої ВEC, так і електроенергії, необхідної для проведення опріснення морської води методом зворотного осмосу та електролітичного виробництва водню, повинні розраховуватись для кожного конкретного випадку з урахуванням всіх факторів, що впливають на роботу даних систем. При розробці конкретних проєктів всі дані, наведені в табл. 1, будуть уточнені залежно від характеристик морської води, вітроенергетичного та опріснювального обладнання, що входитиме до складу морського комплексу 3 отримання зеленого водню.

Південні райони України, де планується розміщення морських офшорних ВEC, характеризуються також високим рівнем надходження сонячного випромінювання. Для масштабного виробництва зеленого водню із застосуванням морських офшорних ВЕС можуть бути використані напрацювання авторів, отримані при розробці проєкту автономного енергокомплексу для електротеплозабезпечення невеликих приморських селищ від відновлюваних джерел енергії та постачання їх прісною водою. Система опріснення морської води й утилізації розсолів являла собою окремий вузол автономного енергокомплексу 3 енергозабезпеченням від вітрової та сонячної енергії, перетвореної в електричну, сонячної теплової енергії і залишкового тепла технологічних циклів [15].

Основні складові елементи системи опріснення: блок енергопостачання, до складу якого входять вітроелектрична установка, сонячна теплова установка, фотоелектричні перетворювачі; блок забору та підготовки води; установки 3 опріснення та регулювання параметрів опрісненої води; резервуари опрісненої технічної та питної води; блок утилізації розсолів. Робота системи опріснення може проводитись за трьома основними технологічними варіантами:

- опріснення морської води методом зворотного осмосу 3 використанням електроенергії, виробленої вітроелектричним та фотоелектричним обладнанням;

- опріснення морської води на вакуумних випарних установках 3 використанням теплової сонячної енергії;

$$
\text { - одночасна робота за двома }
$$

технологічними лініями.

Для забезпечення безперебійної роботи системи необхідно створення запасу морської води в спеціальному резервуарі, яка забирається за традиційною схемою - перед подачею в установку проводиться іiї очистка від макродомішок, відстоювання і фільтрація. 
Пом'якшення води проводиться в спеціальних реакторах, де морська вода змішується з відповідною кількістю необхідних реагентів, перемішується і відстоюється протягом певного часу, декантується і збирається в спеціальній ємності, звідки, за необхідності, поступає на опріснювальні установки. При порівнянні енергетичних витрат на опріснення води значні переваги має застосування установки зворотного осмосу. Крім того, в даному разі опріснена вода не має агресивних властивостей, а ступінь очищення води від деяких сполук за методом зворотного осмосу може сягати 99,6\%. Така ефективність установок дозволяє провадити водоочищення майже для усіх сфер життя та господарської діяльності [16].

Таким чином, весь запропонований процес переробки морської води можна розділити на три основних етапи: пом'якшення води й одержання добрив, опріснення води, утилізація розсолів. Добриво може бути ефективно використане для підвищення урожайності сільськогосподарських рослин. Для виділення мікроелементів з розсолів було запропоновано сорбційний метод, що дає змогу швидко й ефективно переробляти великі об'єми розчинів. Розділення концентрату мікроелементів на простіші за складом фракції проводиться при використанні різних сорбентів, солі цінних металів виділяються із розчинів випарюванням. Продукти, одержані в процесі переробки розсолів, придатні для використання в хімічній промисловості [16].

Крім удосконалення існуючих технологій опріснення морської води, проводяться дослідження в напрямі пошуку альтернативних можливостей та створення нових технологій. Дослідники з Університету Центральної Флориди
(UCF) розробили нанорозмірний матеріал, який ефективно розщеплює морську воду на кисень та водень. Тонкоплівковий матеріал було отримано 3 використанням поверхневих наноструктур із селеніду нікелю, легованих залізом та фосфором. Результатом використання цієї комбінації $\epsilon$ стабільність з високою продуктивністю на рівнях, необхідних для промислового електролізу. Дослідники заявляють, що ефективність електролізу морської води, досягнута подвійною легованою плівкою, значно перевершує показники останніх заявлених найсучасніших каталізаторів електролізу та відповідає вимогам, необхідним для практичного застосування в промисловості [17].

У Великобританії команда дослідників створила сито на основі графену, яке здатне відсіювати солі з морської води. Сито з оксиду графену може виявитися особливо ефективним в очищенні води від солей і невдовзі його почнуть тестувати, порівнюючи з уже наявними мембранами для опріснення. Кінцевою метою наукових досліджень $€$ створення фільтраційного пристрою, який на виході даватиме питну воду з солоної або стічної води, споживаючи при цьому якнайменше енергії. Графенові мембрани мають великі перспективи в опрісненні морської води [18].

На основі полімерних нановолокон, сформованих в електростатичному полі, вчені 3 Республіки Корея створили фільтр, який відділяє від морської води 99,9 \% солей. Розробники вважають, що в результаті комерціалізації відкриття промислові опріснювальні установки зможуть готувати прісну воду за дуже короткий термін. Це буде значно простіше й ефективніше роботи сучасних опріснювальних станцій на 
основі зворотного осмосу, оскільки не потребує витрат енергіi, а відділені солі можна направити на подальше використання [19].

У ціновому плані вартість отриманого зеленого водню може впасти нижче 2 доларів за кілограм, оцінка досить прийнятна, щоб конкурувати протягом десятиліття. Це відкриває шлях для збільшення масштабів виробничих потужностей, нових робочих місць та економічного зростання. Вже зараз спостерігається поліпшення прогнозів витрат на зелений водень. Такі результати ще недавно не очікувались до середини століття [14]. Значні зусилля науковців світу направлені на підвищення ефективності проведення електролізу води. Так, компанія Cummins працює над автоматизацією процесу виробництва твердооксидних електролізерів (SOEC) для розвитку водневої економіки та забезпечення понад $100 \mathrm{MBT}$ виробничих потужностей електролізера. Передбачається створення ефективніших електролізерів при одночасному зменшенні капітальних витрат [20].

Оскільки більша частина виробничих витрат при отриманні зеленого водню припадає на електроенергію від офшорних ВЕС, прогнозоване зменшення витрат на виробництво електроенергії за рахунок зменшення витрат на енергетичне обладнання, збільшення коефіцієнта використаної потужності ВEC та підвищення ефективності процесу електролізу дозволить значно знизити загальні витрати і зменшити вартість зеленого водню.

Висновки. Запровадження в Україні нового європейського підходу до наукових досліджень і розробок в енергетиці насамперед передбачає орієнтацію на впровадження технологій використання відновлюваних джерел енергії, а також на розвиток потужних систем акумулювання енергії. Безвуглецеве виробництво електроенергії, високий коефіцієнт встановленої потужності та постійне зменшення капітальних витрат роблять офшорну вітроенергетику привабливою технологією для виробництва зеленого водню.

Зелений водень, що вироблятиметься методом електролітичного розкладу води 3 використанням морської вітрової енергї як первинного енергоресурсу, має перспективу стати ключовим елементом декарбонізованої енергетики України. Створення ефективних проєктів на основі морських відновлюваних джерел із застосуванням морської опрісненої води для отримання «зеленого» водню зменшить вплив нерегулярності надходження енергії вітру та підвищить гнучкість енергетичної системи на основі офшорних ВEC, знімаючи проблему необхідності обмеження генерації та примусового відключення вітроелектростанцій. При використанні електроенергії від офшорних ВЕС для виробництва зеленого водню найбільш прийнятним на даний час $є$ опріснення морської води із застосуванням технології зворотного осмосу.

Перспективним планам щодо впровадження 10 ГВт електролізних потужностей в Україні повинна передувати розробка пілотних проєктів різної потужності та різного складу, їх впровадження, дослідження та надання рекомендацій на основі аналізу отриманих результатів. Впровадження пілотних проєктів дасть можливість отримати досвід інтеграції робочих енергетичних систем 3 виробництва зеленого водню в морському середовищі. 
1. Біла Книга 2021 Офшорна вітроенергетика та “зелений” водень: відкриття нових меж енергетичної потужності України. [Електронний pecypc] URL: https://www.ive.org.ua/wpcontent/uploads/2_5438583199909284286.pdf

2. Повханич А.Ю. Вітроенергетика як ключовий елемент енергетичної стратегії. [Електронний ресурс] URL: http://www.visnyk-

econom.uzhnu.uz.ua/archive/13_2_2017ua/19.pdf

3. У Південній Кореї розробили плавучу морську установку, яка вироблятиме водень. [Електронний ресурс]. URL: https://mind.ua/news/20229954-u-pivdennij-koreyirozrobili-plavuchu-morsku-ustanovku-yaka-viroblyatime-voden

4. Петренко К.В., Іванченко І.В., Кармазін О.О. Аналіз водних ресурсів України в контексті можливості іх використання для виробництва «зеленого» водню. Відновлювана енергетика. 2021. № 2(65). С. 19-28.

5. Концептуальне дослідження 3 виробництва зеленого водню 3 морської енергії вітру. [Електронний pecypc]. URL: https://www.h2-view.com/story/conceptual-studyfor-green-hydrogen-production-from-offshore-wind-power-tobe-explored-in-behyond-project/

6. Опріснення морської води. [Електронний ресурс]. URL: https://ecosoft.ua/ua/blog/opresnenie-morskoy-vody/.

7. Методи опріснення при підготовці води для котлів високого i надвисокого тиску. [Електронний ресурс]. URL: https://core.ac.uk/download/pdf/199238488.pdf

8. Опреснение воды: электрические и комбинированные системы. [Електронний ресурс]. URL: https://www.abok.ru/for_spec/articles.php?nid=3610

9. Науковці зі США вдосконалили метод опріснення води. Він дозволяє зробити на $30-40 \%$ більше води придатною до пиття. [Електронний ресурс]. URL: https://hromadske.ua/posts/naukovci-zi-ssha-vdoskonalilimetod-oprisnennya-vodi-vin-dozvolyaye-zrobiti-na-30-40bilshe-vodi-pridatnoyu-do-pittya

10. Опріснення води у Британії: нові технології у країні дощів. [Електронний ресурс].

URL: https://www.dw.com/uk /a-6114704

11. Lhyfe зараз виробляє 300 кг водню щодня 3 а рахунок вітрової енергії. [Електронний ресурс]. URL: https://www.h2-view.com/story/lhyfe-now-producing$300 \mathrm{~kg}$-of-hydrogen-daily-from-wind-power-one-tonne-scale-upplans-announced/.

12. Електролізер $\mathrm{Nel}$ виробляє до 500 кг водню щодня для проєкту PosHYdon. [Електронний ресурс]. URL: https://www.h2-view.com/story/nel-electrolyser-toproduce-up-to-500kg-of-hydrogen-daily-for-the-poshydonproject/

13. Відновлювані джерела енергії. За ред. С.О. Кудрі. Київ. Інститут відновлюваної енергетики НАНУ. 2020. 392 с.

14. Зниження витрат на зелений водень: збільшення масштабу електролізерів для досягнення кліматичної цілі
$1,5^{0}$. Міжнародне агентство з відновлюваних джерел енергії. Абу-Дабі. IRENA. 2020. 117 c.

15. Кудря С.А., Яиенко Л.В., Вахнин И.П., Максин В.И. Система опреснения морской воды и утилизация рассолов с использованием энергии возобновляемых источников. Сб. научн. тр. «Проблемы создания и использования энергии возобновляемых источников энергии». Институт электродинамики АН УССР. 1991. С. 157-166.

16. Кудря С.О., Яиенко Л.В., Шинкаренко Л.Я., Ткаленко М.Д., Будько В.І. Використання вітрової та сонячної енергії для опріснення води. Матеріали XVII-ої міжнародної конференції "Відновлювана енергетика та енергоефективність ХХІ століття”. м. Київ. 29-30 травня 2016 p. C. $229-231$.

17. Виробництво водню з морської води стає ближчим. [Електронний ресурс].

URL: https://www.hydrogenfuelnews.com/hydrogen-fuel-productionseawater/8547742/?mc_cid=292451db93\&mc_eid=cd40454d77

18. Як графен може допомогти 3 опрісненням морської води. [Електронний ресурс]. URL: https://www.bbc.com/ukrainian/features-39490520

19. Корейские учёные придумали эффективный опреснитель морской воды. [Електронний ресурс]. URL: https://www.ukr.net/news/details/science/85928816.html

20. Виробництво електролізерів потужністю 100 МВт за допомогою автоматизації. [Електронний ресурс]. URL: https://www.h2-view.com/story/cummins-targets-100mwelectrolyser-production-capacity-through-automation/

\section{REFERENCES}

1. Bila Knyha 2021 Ofshorna vitroenerhetyka ta "zelenyi" voden: vidkryttia novykh mezh enerhetychnoi potuzhnosti Ukrainy. [White Book 2021 Offshore wind energy and "green" hydrogen: opening new frontiers of Ukraine's energy capacity]. [Electronic resource]. URL: https://www.ive.org.ua/wpcontent/uploads/2_5438583199909284286.pdf. [in Ukrainian].

2.Povkhanych A.Yu. Vitroenerhetyka yak kliuchovyi element enerhetychnoi stratehii. [Wind energy as a key element of energy strategy]. [Electronic resource]. URL: http://www.visnykeconom.uzhnu.uz.ua/archive/13_2_2017ua/19.pdf. [in Ukrainian].

3. U Pivdennii Korei rozrobyly plavuchu morsku ustanovku, yaka vyrobliatyme voden. [South Korea has developed a floating naval installation that will produce hydrogen]. [Electronic resource].

URL: https://mind.ua/news/20229954-u-pivdennij-koreyirozrobili-plavuchu-morsku-ustanovku-yaka-viroblyatime-voden. [in Ukrainian].

4.Petrenko K.V., Ivanchenko I.V., Karmazin O.O. Analiz vodnykh resursiv Ukrainy $\mathrm{v}$ konteksti mozhlyvosti yikh vykorystannia dlia vyrobnytstva «zelenoho» vodniu. [Analysis of water resources of Ukraine in the context of the possibility of their 
use for the production of "green" hydrogen]. Vidnovluvana energetika. 2021. № 2 (65). Pp. 19-28. [in Ukrainian].

5. Kontseptualne doslidzhennia $\mathrm{z}$ vyrobnytstva zelenoho vodniu $\mathrm{z}$ morskoi enerhii vitru. [Conceptual study on the production of green hydrogen from marine wind energy]. [Electronic resource]. URL: https://www.h2view.com/story/conceptual-study-for-green-hydrogenproduction-from-offshore-wind-power-to-be-explored-inbehyond-project/. [in Ukrainian].

6. Oprisnennia morskoi vody. [Desalination of sea water]. [Electronic resource].

URL: https://ecosoft.ua/ua/blog/opresnenie-morskoy-vody/. [in Ukrainian]

7. Metody oprisnennia pry pidhotovtsi vody dlia kotliv vysokoho i nadvysokoho tysku. [Desalination methods in water preparation for high and ultrahigh pressure boilers]. [Electronic resource]. URL: https://core.ac.uk/download/pdf/199238488.pdf. [in Ukrainian].

8. Opresnenie vody: elektricheskie i kombinirovannye sistemy. [Desalination of water: electrical and combined systems]. [Electronic resource].

URL: https://www.abok.ru/for_spec/articles.php?nid=3610

[in Russian]

9.Naukovtsi zi SShA vdoskonalyly metod oprisnennia vody. Vin dozvoliaie zrobyty na $30-40 \%$ bilshe vody prydatnoiu do pyttia. [Scientists from the United States have improved the method of desalination of water. It allows you to make $30-40 \%$ more water suitable for drinking]. [Electronic resource]. URL: https://hromadske.ua/posts/naukovci-zi-ssha-vdoskonalilimetod-oprisnennya-vodi-vin-dozvolyaye-zrobiti-na-30-40bilshe-vodi-pridatnoyu-do-pittya. [in Ukrainian].

10. Oprisnennia vody u Brytanii: novi tekhnolohii u kraini doshchiv. [Water desalination in Britain: new technologies in the land of rain]. [Electronic resource]. URL: https://www.dw.com/uk /a-6114704. [in Ukrainian].

11. Lhyfe zaraz vyrobliaie $300 \mathrm{~kg}$ vodniu shchodnia za rakhunok vitrovoi enerhii. [Lhyfe now produces $300 \mathrm{~kg}$ of hydrogen daily due to wind energy]. [Electronic resource]. URL: https://www.h2-view.com/story/lhyfe-now-producing$300 \mathrm{~kg}$-of-hydrogen-daily-from-wind-power-one-tonne-scale-upplans-announced/. [in Ukrainian].

12. Elektrolizer Nel vyrobliaie do $500 \mathrm{kh}$ vodniu shchodnia dlia proiektu PosHYdon. [The Nel cell produces up to $500 \mathrm{~kg}$ of hydrogen per day for the PosHYdon project]. [Electronic resource]. URL: https://www.h2-view.com/story/nelelectrolyser-to-produce-up-to-500kg-of-hydrogen-daily-for-theposhydon-project/. [in Ukrainian].
13. Vidnovliuvani dzherela enerhii. [Renewable energy sources]. Za red. S.O. Kudri. Kyiv. Instytut vidnovliuvanoi enerhetyky NANU. 2020. 392 p. [in Ukrainian].

14. Znyzhennia vytrat na «zelenyi» voden: zbilshennia masshtabu elektrolizeriv dlia dosiahnennia klimatychnoi tsili $1,5^{\circ}$. [Reducing the cost of "green" hydrogen: increasing the scale of the cells to achieve the climate goal of $1.5^{\circ}$ ]. International Renewable Energy Agency. Abu Dhabi. IRENA. 2020. 117 p. [in Ukrainian].

15. Kudrya S.A., Yacenko L.V., Vahnin I.P., Maksin V.I. Sistema opresneniya morskoj vody i utilizaciya rassolov $\mathrm{s}$ ispol'zovaniem energii vozobnovlyaemyh istochnikov. [Seawater desalination system and brine utilization using renewable energy sources]. Sb. nauchn. tr. «Problemy sozdaniya i ispolzovaniya energii vozobnovlyaemyh istochnikov energii». Institute of Electrodynamics of the Academy of Sciences of the Ukrainian SSR. 1991. Pp. 157-166. [in Russian].

16. Kudria S.O., Yatsenko L.V., Shynkarenko L.Ia., Tkalenko M.D., Budko V.I. Vykorystannia vitrovoi ta soniachnoi enerhii dlia oprisnennia vody. [Use of wind and solar energy for water desalination]. Materialy XVII-oi mizhnarodnoi konferentsii "Vidnovliuvana enerhetyka ta enerhoefektyvnist XXI stolittia". Kyiv. 29-30 may 2016. Pp. 229-231.

[in Ukrainian]

17. Vyrobnytstvo vodniu z morskoi vody staie blyzhchym. [Hydrogen production from seawater is getting closer]. [Electronic resource].

URL: https://www.hydrogenfuelnews.com/hydrogen-fuel-productionseawater/8547742/?mc_cid=292451db93\&mc_eid=cd40454d77 [in Ukrainian].

18. Iak hrafen mozhe dopomohty z oprisnenniam morskoi vody. [How graphene can help with seawater desalination]. [Electronic resource]. [in Ukrainian].

URL: https://www.bbc.com/ukrainian/features-39490520

19. Korejskie uchyonye pridumali effektivnyj opresnitel' morskoj vody. [Korean scientists come up with an effective seawater desalination]. [Electronic resource]. URL: https://www.ukr.net/news/details/science/85928816.html [in Russian]

20. Vyrobnytstvo elektrolizeriv potuzhnistiu $100 \mathrm{MVt}$ za dopomohoiu avtomatyzatsii. [Production of electrolyzers with a capacity of $100 \mathrm{MW}$ through automation]. [Electronic resource]. URL: https://www.h2-view.com/story/cummins-targets-100mwelectrolyser-production-capacity-through-automation/.

[in Ukrainian]. 